\title{
Bud take success, growth and foliage characters of different Prunus cultivars on Myrocal and Julior clonal rootstock
}

\author{
Ritu Sharma* and Amit Kumar ${ }^{1}$ \\ Division of Fruit Science, University of Horticulture and Forestry, Nauni, Solan-173 230 (HP), INDIA \\ ${ }^{1}$ Division of Fruit Science, SKUAST-Kashmir, Shalimar, Srinagar- 190025 (J\&K), INDIA \\ *Corresponding author E-mail: reet_libra21@yahoo.co.in \\ Received: September 02, 2015; Revised received: July 30, 2016; Accepted: July 23, 2016
}

\begin{abstract}
The present study determined the effect of clonal rootstock of Prunus and their graft compatibility with peach, plum and apricot cultivars. Prunus scion cultivars were tongue grafted on respective Prunus clonal rootstocks in the last week of January, 2006. The study indicated that with respect to graft success, Myrocal exhibited higher bud take with apricot (66.67\%) than plums (63.89 \%) with 1.15 and 1.20 stock/scion ratio, respectively. Julior exhibited higher bud take with plums $(91.77 \%)$ than peaches $(86.11 \%)$ with 1.10 and 1.07 stock/scion ratio, respectively, whereas, Julior exhibited higher bud take with plum $(91.77 \%)$ than peaches $(86.11 \%)$ with 1.10 and 1.07 stock/ scion ratio, respectively. Comparative studies indicate higher bud take of plum cvs Frontier $(91.64 \%)$ and Red Beaut $(91.84 \%)$ on Julior as compared to Myrocal. Peach scion cultivars recorded more annual growth in terms of plant height $(0.73 \mathrm{~m})$ and plant spread $(0.48 \mathrm{~m} \times 0.62 \mathrm{~m})$ than plum scion cultivars on Julior. Contrary to higher vigour recorded in nectarine scions compared to peach scions grafted on Julior, annual growth has been observed to be higher in peaches than in nectarines. Comparative studies indicate plant height, plant spread, trunk girth, internodal length and pruning weight of both plum cultivars to be higher on Myrocal than on Julior. With the present study, it is clear that Myrocal is more vigorous than Julior rootstock and both the rootstocks can be utilized for propagation with Prunus cultivars studied.
\end{abstract}

Keywords: Clonal rootstock, foliage, Julior, Growth, Myrocal, Prunus

\section{INTRODUCTION}

Cultivation of peaches, plums and apricots is primarily concentrated to North Indian hilly states (Jammu and Kashmir, Himachal Pradesh, Uttarakhand), north eastern states and few low chilling cultivars have occupied a place in the states of Punjab, Haryana and Uttar Pradesh. Still as compared to world standards, there are very low productivity levels of these stone fruits in India, despite the fact that these fleshy stone fruits are cherished commodities reaching the fresh markets at the earliest in the season when virtually no other fruits are available in the market. One of the major reasons of low productivity of peaches, plums and apricots is the continued use of seedling stocks beneath these fruits unlike clonal rootstocks elsewhere. The rootstocks are known to have a profound effect on vigour, precocity, productivity, fruit quality and tree longevity of scion varieties (Schiaffino and Radice, 2009).

Seedling rootstocks in vague, though well adapted, being hardy bear more heavily and long lived but lack certain important characteristics like short juvenility, uniformity in growth excessive vigorous, susceptible to seed borne disease and production of inferior quality fruits etc. On the other hand, clonal rootstocks possess requisite attributes such as uniformity, tree size con- trol, precocity, cropping efficiency and resistance to various stresses (Hartmann, 1987; Webster, 2002; Gainza et al., 2015).

Clonal rootstock research has received considerable attention in developed countries of the world and large number of clonally propagated rootstocks has been developed. In contrast, very little work has been done in India either to develop or to select suitable rootstock for various stone fruits. Keeping in view the fact and to overcome the problems related to seedling rootstocks few Prunus clonal rootstocks have been introduced recently from France by the Department of Fruit Breeding \& Genetic Resources of Dr. Y.S. Parmar University of Horticulture and Forestry, Nauni, Solan for determining their suitability under local conditions. These clonal rootstocks are considered to be compatible with most of the peach, plum and apricot cultivars grown in areas similar to their region of development. Notwithstanding this fact and the belief that a rootstock, no matter how good it is, cannot be promoted unless its propagability, graft compatibility with scion cultivars of regional importance and effects on scion characteristics are determined and is found good enough meeting local needs. Therefore the present study was conducted to determine the suitability of these clonal rootstocks for different cultivars of peach, plum and apricot. 


\section{MATERIALS AND METHODS}

Study area: The present investigations were carried out in the experimental block of the Department of Fruit Breeding and Genetic Resources, University of Horticulture and Forestry, Nauni, Solan (Himachal Pradesh). Experimental farm is situated at an elevation of 1240 metres above mean sea level and lies between $30^{\circ} 50^{\prime} \mathrm{N}$ latitude and $77.08^{\circ} \mathrm{E}$ longitude. The soil of the experimental land exhibits sandy loam texture. Summer is moderately hot during May-June (31.8$34.8^{\circ} \mathrm{C}$ ) while winter is cold during December-January $\left(2.4-3.7^{\circ} \mathrm{C}\right)$. The average annual temperature ranges from 12.4 to $25.4^{\circ} \mathrm{C}$. The average annual rainfall ranges from $100-130 \mathrm{~cm}$, major portion of which is received during monsoon (July-August). Winter rains are usually of lighter intensity and of shorter durations. Planting material and grafting procedure: The experimental plant material comprised of two clonal rootstocks of Prunus species viz., Myrocal and Julior introduced from France and planted in the experimental farms of Department of Fruit Breeding and Genetic Resources at a spacing of $3 \times 3$ metres $(\mathrm{m})$. Various Prunus scion cultivars were tongue grafted on respective Prunus clonal rootstocks in the last week of January. Details of scion cultivar and their combination with clonal rootstock are given here.

Observations recorded and statistical analysis: $\mathrm{Ob}$ servations were recorded on various graft compatible (graft success/bud take success which was recorded after two months of grafting in all the combinations (\%), stock/ scion ratio was calculated by dividing trunk girth of stock with trunk girth of scion. Growth parameters viz. plant height $(\mathrm{m})$, plant spread $(\mathrm{m})$, trunk girth $(\mathrm{cm})$, branching density, internodal length and pruning weight $(\mathrm{g})$ and foliage characters (leaf bud burst time, leaf area $\left(\mathrm{cm}^{2}\right)$ were also recorded as per their procedure. Stomatal density and size was calculated as described by Beakbane and Majumdar (1975). For the estimation of chlorophyll content (mg/g fresh weight of leaves) the leaf samples were prepared as per the method suggested by (Halfacre et al., 1968) and according to the formula given by Hiscox and Israeeistam (1979). Time of leaf fall was calculated after completion of 75 per cent leaf fall. The experiment was replicated thrice and the data were analysed in RBD. Contrast methods were applied between rootstocks and between scion cultivars within each rootstock as suggested by Gomez and Gomez (1984).

\section{RESULTS AND DISCUSSION}

\begin{tabular}{|c|c|}
\hline $\mathbf{R o 0}$ & \\
\hline $\begin{array}{l}\text { Myrocal ( } P \text {. cerasif- } \\
\text { era) }\end{array}$ & $\begin{array}{l}\text { d Beaut, Santa R } \\
\text { er } \\
\text { New Castle }\end{array}$ \\
\hline $\begin{array}{l}\text { Julior [St.Julien }(P \text {. } \\
\text { insititia }) \text { x Pershore } \\
(P \text {. domestica })]\end{array}$ & $\begin{array}{l}\text { Peach: July Elberta, } \\
\text { Redhaven } \\
\text { Plum : Red Beaut, Frontier }\end{array}$ \\
\hline
\end{tabular}

Graft compatibility : Graft success of different stionic combinations with Prunus clonal rootstocks is presented in Table 1.

Myrocal : On 'Myrocal' highest bud take success was 91.67 per cent in 'Santa Rosa' plum and was statistically different from 66.67 per cent in 'Frontier' and 33.33 per cent in 'Red Beaut'. The latter two were also statistically different for bud take success. Overall in plum and apricot on 'Myrocal' no significant difference for bud take was observed, however bud take success of 66.67 per cent in apricot cv. 'New Castle' was little higher than 63.89 per cent in plum. Maximum stock/scion ratio in plum cultivars was 1.26 in 'Santa Rosa' followed by 1.19 in 'Frontier' and 1.14 in 'Red Beaut'. The differences observed for stock/scion ratio in plum cultivars were statistically significant. Overall stock/scion ratio of 1.20 in plum cultivars and 1.15 in apricot cv. New Castle was observed to be statistically at par. With respect to 'Myrocal', bud take success and stock/scion ratio of plum and apricot as scions was at par whereas, within plum cvs. 'Santa Rosa', 'Frontier' and 'Red Beaut' these two parameters differed significantly. It appears that these differences are more due to the influence of scion rather than that of rootstock. On the contrary, Sharma and Sharma (1986b) found that rootstock effect was more marked than the scion effect while evaluating 'Santa Rosa', 'Mariposa' and 'Green Gage' plums grafted on wild peach, wild apricot and Myrobalan B.

Julior : Data on bud take and stock/scion ratio of peach and plum cultivars grafted on 'Julior' rootstock was presented in Table 1. Bud take to the extent of 97.22 per cent in 'Redhaven' was observed to be significantly different from 75.00 per cent in 'July Elberta', however, the difference for stock/scion ratio in 'July Elberta' (1.07) and 'Redhaven' (1.06) on 'Julior' was statistically at par. Among plum cultivars, bud take of 91.87 per cent in 'Red Beaut' was little higher than 91.67 per cent in 'Frontier' but statistically at par, however, stock/scion ratio of 1.27 in 'Frontier' was statistically higher than 'Red Beaut' (0.93). Overall bud take percentage of 91.77 per cent in plum was found to be significantly superior to peach $(86.11 \%)$. Similarly, stock/scion ratio of 1.10 in plum was significantly different and higher than 1.07 in peach on 'Julior'. Bud take was significantly higher with plums than with peaches and so was the stock/scion ratio when grafted on 'Julior' rootstock. These findings are in accordance with those of Nisar et al. (2002) who also obtained 90.0 per cent bud take success in plum cultivars budded on peach rootstock. Among the peach cultivars 'Redhaven' and 'July Elberta' on 'Julior', bud take success was significantly different while stock/scion ratio was at par. On the contrary plum cultivars 'Frontier' and 'Red Beaut' were at par for bud take success but significantly different for stock/scion ratio.

However present findings are in line with several other 
Table 1. Graft success and annual growth extension $\left(1^{\text {st }}-2^{\text {nd }}\right.$ year $)$ of different scion cultivars on Prunus clonal rootstocks.

\begin{tabular}{|c|c|c|c|c|c|c|}
\hline \multirow[b]{2}{*}{ Treatments } & \multicolumn{2}{|c|}{ Graft Success } & \multirow{2}{*}{$\begin{array}{c}\text { Plant } \\
\text { height } \\
\text { (m) }\end{array}$} & \multirow{2}{*}{$\begin{array}{c}\text { Trunk } \\
\text { girth } \\
(\mathrm{mm})\end{array}$} & \multicolumn{2}{|c|}{ Plant spread (m) } \\
\hline & $\begin{array}{c}\text { Bud take } \\
(\%)\end{array}$ & $\begin{array}{c}\text { Stock/scion } \\
\text { ratio }\end{array}$ & & & $\begin{array}{c}\text { North-South } \\
\text { (NS) }\end{array}$ & $\begin{array}{c}\text { East-West } \\
(\text { EW })\end{array}$ \\
\hline \multicolumn{7}{|l|}{ Myrocal (P. cerasifera) } \\
\hline \multicolumn{7}{|l|}{ Plum cultivars } \\
\hline Red Beaut & 33.33 & 1.14 & 0.60 & 16.54 & 0.47 & 0.50 \\
\hline Santa Rosa & 91.67 & 1.26 & 0.46 & 4.18 & 0.21 & 0.19 \\
\hline Frontier & 66.67 & 1.19 & 0.53 & 6.28 & 0.50 & 0.41 \\
\hline $\mathrm{CD}_{0.05}$ & 4.57 & 0.04 & 0.07 & 0.92 & 0.07 & 0.12 \\
\hline Plum & 63.89 & 1.20 & 0.53 & 9.0 & 0.39 & 0.37 \\
\hline Apricot (cv. New Castle) & 66.67 & 1.15 & 0.39 & 11.85 & 0.26 & 0.19 \\
\hline $\mathrm{CD}_{0.05}$ & 13.39 & 0.11 & 0.20 & 2.70 & 0.21 & 0.34 \\
\hline \multicolumn{7}{|c|}{ Julior (St. Julien x Pershore) } \\
\hline \multicolumn{7}{|l|}{ Peach cultivars } \\
\hline July Elberta & 75.00 & 1.07 & 0.74 & 10.26 & 0.52 & 0.70 \\
\hline Redhaven & 97.22 & 1.06 & 0.72 & 10.41 & 0.44 & 0.53 \\
\hline $\mathrm{CD}_{0.05}$ & 4.57 & 0.04 & 0.07 & 0.92 & 0.07 & 0.12 \\
\hline \multicolumn{7}{|l|}{ Plum cultivars } \\
\hline Frontier & 91.67 & 1.27 & 0.38 & 5.54 & 0.45 & 0.30 \\
\hline Red Beaut & 91.87 & 0.93 & 0.53 & 16.36 & 0.26 & 0.28 \\
\hline $\mathrm{CD}_{0.05}$ & 4.57 & 0.04 & 0.07 & 0.92 & 0.07 & 0.12 \\
\hline Peach & 86.11 & 1.07 & 0.73 & 10.34 & 0.48 & 0.62 \\
\hline Plum & 91.77 & 1.10 & 0.46 & 10.95 & 0.36 & 0.29 \\
\hline $\mathrm{CD}_{0.05}$ & 2.29 & 0.02 & 0.03 & 0.46 & 0.04 & 0.06 \\
\hline
\end{tabular}

studies on bud take success where earlier Perry et al., (2000) reported 52 per cent success with Citation rootstock when grafted with Redhaven peach, however, Zeb et al., 2002 reported 89.97 per cent bud take success in Florida King peach budded on Peshawar local rootstock. Nisar et al., 2002 recorded 50.0 to 90.0 per cent bud take success in apricot and plum, respectively budded on peach rootstock. Nine peach rootstocks were grafted with Suncrest cultivars of peach in different districts of Italy and it was observed that Julior showed most successful results (Salvador et al., 2002). Ahmad et al., (2012) recorded 85.0 per cent bud take success while budding Early Grande peach on seedling rootstock.

Although it is a general opinion that overgrowth of scion indicates graft incompatibility but in several cases it has been seen that such graft unions showed no signs of incompatibility later on (Westwood, 1978). The level of bud take success obtained in the present studies or in other words survival rate of different scion cultivars on Prunus clonal rootstocks coupled with stock/scion ratio around 1.0 in most cases indicates moderate to high levels of graft compatibility with respective scion cultivars.

Annual growth extension of scion cultivars : Data on annual growth extension of various scion cultivars grafted on different Prunus clonal rootstocks was presented in Table 1.

Myrocal: Annual extension growth with respect to maximum plant height $(0.60 \mathrm{~m})$ was recorded in 'Red Beaut' plum and was statistically at par with 'Frontier' $(0.53 \mathrm{~m})$ and 'Frontier' was statistically at par with 'Santa Rosa' $(0.46 \mathrm{~m})$. Annual increase in trunk girth recorded in 'Red Beaut' (16.54 mm),
'Frontier' (6.28 mm) and 'Santa Rosa' (4.18 mm) plum was significantly different from each other. Annual growth for plant spread was recorded maximum in 'Frontier' $(0.50 \mathrm{~m})$ for NS direction which was statistically at par with 'Red Beaut' $(0.47 \mathrm{~m})$. Maximum increase in plant spread towards EW direction was recorded in 'Red Beaut' $(0.50 \mathrm{~m})$ which was statistically at par with 'Frontier' $(0.41 \mathrm{~m})$. Minimum increase in plant spread was observed in 'Santa Rosa' for NS $(0.21 \mathrm{~m})$ and EW $(0.19 \mathrm{~m})$ directions, respectively. Among plum and apricot, overall annual extension growth in plant height and plant spread in NS and EW directions, though higher in plum $(0.53 \mathrm{~m}, 0.39 \mathrm{~m}$, $0.37 \mathrm{~m}$, respectively) than apricot $(0.39 \mathrm{~m}, 0.26 \mathrm{~m}$, $0.19 \mathrm{~m}$, respectively) but was statistically at par with each other. However, increase in annual extension for trunk girth was significantly higher in apricot (11.85 $\mathrm{mm})$ than plum $(9.00 \mathrm{~mm})$.

As regards annual extension, growth of plum scions was higher than in apricot on Myrocal expect for trunk girth. Varying levels of extension in annual growth were also observed between three plum cultivars grafted on Myrocal, with Red Beaut excelling over Santa Rosa and Frontier with respect to increase in plant height and trunk girth. Two plum cultivars were grafted on seedling and asexually rootstocks and it was observed that both St. Julien A and Pixy rootstock showed smaller canopy width and TCSA (Boyhan et al., 1998). Hrotko et al., 1998 grafted three plum cultivars with six Prunus rootstocks and reported largest TCSA, canopy area and canopy volume with Marianna 'GF 8-1' and Myrobalan 'C 162/a', while small tree size was achieved by Sainte Julien 'GF 655/2', and Prunus domes- 
Ritu Sharma and Amit Kumar / J. Appl. \& Nat. Sci. 8 (3): 1326 - 1332 (2016)

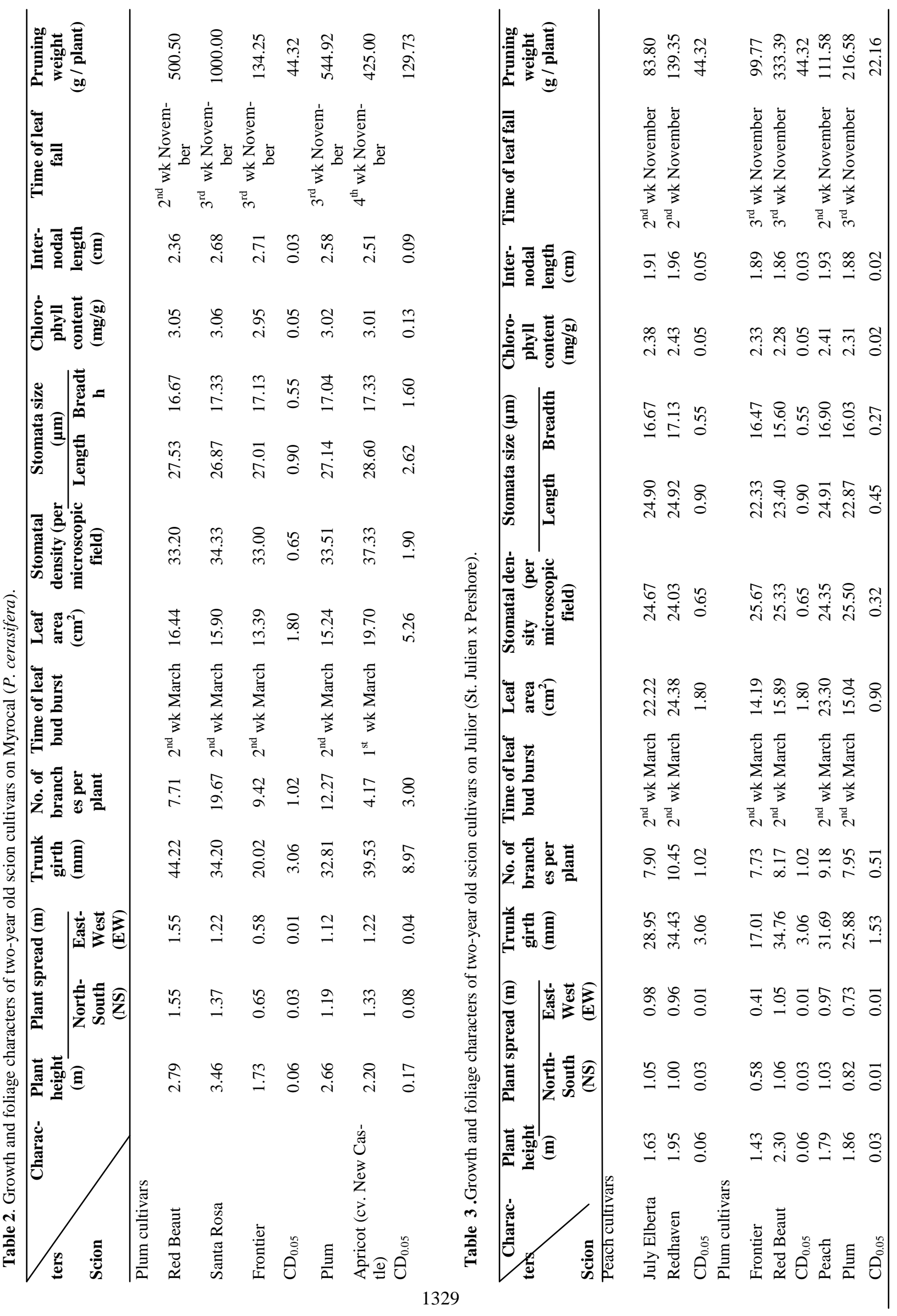


tica 'Fehér besztercei' rootstock. Sitarek et al., 2004 reported maximum growth of five plum cultivars (Oullins Golden Gage, Cacanska Najbolja, Stanley, Empress and Valor) grafted on $P$. divaricata rootstock.

Julior : Data on annual extension growth of peach and plum cultivars as affected by 'Julior' rootstock revealed that increase in plant height among peach cultivars was higher in 'July Elberta' $(0.74 \mathrm{~m})$ and statistically at par with 'Redhaven' $(0.72 \mathrm{~m})$, whereas, annual extension in trunk girth $(10.41 \mathrm{~mm})$ was maximum in 'Redhaven' (10.41 mm) which was statistically higher than 'July Elberta' (10.26 mm). Increase in annual extension growth with respect to plant spread in NS and EW directions among 'July Elberta' (0.52 $\mathrm{m}$ and $0.70 \mathrm{~m})$ and 'Redhaven' $(0.44 \mathrm{~m}$ and $0.53 \mathrm{~m})$ was statistically different. Among plum cultivars, annual increase in plant height $(0.53 \mathrm{~m})$ and trunk girth $(16.36$ $\mathrm{mm})$ was statistically higher in 'Red Beaut' than 'Frontier' ( $0.38 \mathrm{~m}$ and $5.54 \mathrm{~mm}$, respectively). Annual extension in plant spread under NS directions was significantly higher $(0.45 \mathrm{~m})$ in 'Frontier' than 'Red Beaut' $(0.26 \mathrm{~m})$, while annual extension in plant spread under EW directions was statistically at par between 'Frontier' $(0.30 \mathrm{~m})$ and 'Red Beaut' $(0.28 \mathrm{~m})$. Among peach and plum on 'Julior' rootstock, statistically higher annual extension in peach for plant height, plant spread in NS and EW directions was recorded as $0.73 \mathrm{~m}, 0.48 \mathrm{~m}$ and $0.62 \mathrm{~m}$, respectively than plum $(0.46 \mathrm{~m}, 0.36 \mathrm{~m}$ and $0.29 \mathrm{~m}$, respectively). Whereas reverse trend was observed for trunk girth i.e. higher in plum $(10.95 \mathrm{~mm})$ than in peach $(10.34 \mathrm{~mm})$. Peach scions recorded more annual extension growth in terms of plant height and plant spread than plum scions on 'Julior'. 'July Elberta' peach recorded higher increase in plant height and plant spread than 'Redhaven' who exceed in trunk girth as compared to 'July Elberta'. Amongst plum cultivars, 'Red Beaut' exhibited more extension in plant height and trunk girth than in 'Frontier'. Among four cultivars of peach budded on two peach rootstocks Florida King have maximum values for most of the growth and foliage characters (Zeb et al., 2002) however, maximum growth and maximum foliage was observed in plum cultivar when grafted on peach rootstock (Nisar et al., 2002). The trends in annual extension growth of scion cultivars on different rootstocks reveals that the effect of rootstock is of little significance, rather it is more due to the inherent growth potential of the scion cultivar. However, as per Renaud and Salesses (1994) the effect of rootstock on scion is different according to variety.

Growth and foliage characteristics : Data on different growth and foliage characters of two-year old scion cultivars on Prunus clonal rootstocks is presented in Tables 2 and 3.

Myrocal: Significant differences for plant height were observed among plum cultivars (Table 2). Maximum plant height was recorded in 'Santa Rosa' (3.46 m) followed by 'Red Beaut' (2.79 m) and 'Frontier' (1.73 $\mathrm{m})$ which were statistically differ from each other. Statistically different values were recorded for plant spread in NS and EW directions, trunk girth and number of branches per plant in 'Red Beaut' $(1.55 \mathrm{~m}, 1.55$ $\mathrm{m}, \quad 44.22 \mathrm{~mm}$ and 7.71 , respectively), 'Santa Rosa' (1.37 m, $1.22 \mathrm{~m}, 34.20 \mathrm{~mm}$ and 19.67, respectively) and 'Frontier' plum $(0.65 \mathrm{~m}, 0.58 \mathrm{~m}, 20.02 \mathrm{~mm}$ and 9.42, respectively). Maximum leaf area was recorded in 'Red Beaut' $\left(16.44 \mathrm{~cm}^{2}\right)$ closely and statistically followed by 'Santa Rosa' $\left(15.90 \mathrm{~cm}^{2}\right)$ however, minimum leaf area was observed in 'Frontier' (13.39 $\mathrm{cm}^{2}$ ), whereas maximum chlorophyll content was in 'Santa Rosa' (3.06 mg/g) closely followed in 'Red Beaut' $(3.05 \mathrm{mg} / \mathrm{g})$ whereas minimum and statistically different was in 'Frontier' $(2.95 \mathrm{mg} / \mathrm{g})$.

Maximum stomatal density (34.33 per microscopic field) recorded in 'Santa Rosa' was significantly different from 33.20 in 'Red Beaut' and 33.00 in 'Frontier' while latter two cultivars were at par with each other. No significant difference was recorded in 'Red Beaut' (27.53 $\mu \mathrm{m})$, 'Frontier' (27.01 $\mu \mathrm{m})$ and 'Santa Rosa' (26.87 $\mu \mathrm{m})$ for stomata length, and also the difference among 'Frontier' $(17.13 \mu \mathrm{m})$ and 'Red Beaut' $(16.67 \mu \mathrm{m})$ for stomatal breadth was nonsignificant. Stomata breadth $(17.33 \mu \mathrm{m})$ in 'Santa Rosa' was, however, maximum and significantly different from that in 'Red Beaut', but at par with 'Frontier'. Maximum internodal length recorded in 'Frontier' $(2.71 \mathrm{~cm})$ was at par with 'Santa Rosa' (2.68 $\mathrm{cm}$ ) while $2.36 \mathrm{~cm}$ in 'Red Beaut' was found to be significantly different from 'Frontier' and 'Santa Rosa'. The difference for pruning weight was found to be significant in plum being maximum in 'Santa Rosa' (1000.0 g/plant) followed by 'Red Beaut' (500.50 g/plant) and 'Frontier' (134.25 g/plant). Time of leaf bud burst in 'Red Beaut', 'Santa Rosa' and 'Frontier' was second week of March, whereas, time of leaf fall recorded was early $\left(2^{\text {nd }}\right.$ week November) in 'Red Beaut' and late ( $3^{\text {rd }}$ week November) in 'Santa Rosa' and 'Frontier'.

Overall plum and apricot on 'Myrocal' rootstock differed significantly for plant height, plant spread, number of branches and stomatal density. Non-significant differences were observed for the characters to trunk girth, internodal length, leaf area, size of stomata, chlorophyll content and pruning weight (Table 2). Apricot recorded early leaf bud burst time ( $1^{\text {st }}$ week March) than plum ( $2^{\text {nd }}$ week March), whereas plum $\left(3^{\text {rd }}\right.$ week November) was earlier to shed its leaves than apricot ( $4^{\text {th }}$ week November).

Overall more vigorous growth was recorded in plums than in apricot on Myrocal. Such a trend has been observed in earlier studies also in plum cultivars grafted on Myrobalan rootstocks compared to other plum rootstocks (Hartmann, 1987; Rozpara and Grzyb, 1994) and in apricot cv. S. Castrese on various Prunus root- 
stocks (Bassi, 2003). Similar effect of scion growth on Prunus rootstocks was observed by many other workers (Renaud and Salesses, 1994; Simard and Olivier, 1998; Giorgio and Gallotta, 2000). As regards foliage characteristics viz., leaf area, chlorophyll content and size of stomata, plums and apricots as scions were at par on Myrocal except lower stomatal density recorded in plums than in apricot on Myrocal. Higher stomatal density and increased accumulation of chlorophyll content in the leaves of scion cultivars are generally correlated with rootstock effect (Miller, 1977; Makariev et al., 1986).

Julior : When grafted on 'Julior' clonal rootstock, higher plant height $(1.95 \mathrm{~m})$, trunk girth $(34.43 \mathrm{~mm})$, internodal length $(1.96 \mathrm{~cm})$, number of branches per plant (10.45), leaf area $\left(24.38 \mathrm{~cm}^{2}\right)$, stomata length $(24.92 \mu \mathrm{m})$, stomata breadth $(17.13 \mu \mathrm{m})$, chlorophyll content $(2.43 \mathrm{mg} / \mathrm{g})$ and pruning weight (139.35 g/ plant) was recorded in 'Redhaven' peach (Table 3) while plant spread in NS $(1.05 \mathrm{~m})$ and EW $(0.98 \mathrm{~m})$ directions and stomatal density per microscopic field (24.67) was higher in 'July Elberta'. 'Redhaven' and 'July Elberta' peach differed significantly for plant height, plant spread (NS and EW), trunk girth, number of branches, leaf area and pruning weight, whereas non -significant differences were observed for stomatal density, stomata size, chlorophyll content and internodal length. Leaf bud burst time was second week of March in 'July Elberta' as well as in 'Redhaven'. Similarly time of leaf fall was second week of November in both the peach cultivars and exhibited erect growth habit on 'Julior'. Significantly higher values was observed with respect to plant height $(2.30 \mathrm{~m})$, plant spread-NS $(1.06 \mathrm{~m})$, plant spread-EW $(1.05 \mathrm{~m})$, trunk girth $(34.76 \mathrm{~mm})$, stomata length $(23.40 \mu \mathrm{m})$ and pruning weight (333.39 g/plant) in 'Red Beaut' plum as compared to 'Frontier' $(1.43 \mathrm{~m}, 0.58 \mathrm{~m}, 0.41 \mathrm{~m}, 17.01$ $\mathrm{mm}, 22.33 \mu \mathrm{m}$ and $99.77 \mathrm{~g} / \mathrm{plant}$, respectively). Statistically at par values were recorded between 'Red Beaut' and 'Frontier' plum for number of branches (8.17 and 7.73), leaf area (15.89 and $14.19 \mathrm{~cm}^{2}$ ), stomatal density (25.33 and 25.67 per microscopic field), chlorophyll content ( 2.28 and $2.33 \mathrm{mg} / \mathrm{g}$ ) and internodal length $(1.86$ and $1.89 \mathrm{~cm})$. Leaf bud burst time in both the plum cultivars was second week of March and that of leaf fall was third week of November. In a recent study on vegetative behavior of Forastero peach cultivar grafted on different Prunus rootstocks, Radice et al. (2004) recorded intermediate values for internodal length, leaf area, chlorophyll content and pruning weight on Julior and Mr.S.2/5 rootstocks as compared to higher corresponding values on GF 655/2 and Brompton.

Overall on 'Julior' rootstock, plant height, stomatal density and pruning weight recorded as $1.86 \mathrm{~m}, 25.50$ per microscopic field and $216.58 \mathrm{~g} /$ plant, respectively, was found to be significantly higher in plum than in peach which recorded corresponding values of $1.79 \mathrm{~m}$, 24.35 stomata per microscopic field and $111.58 \mathrm{~g} /$ plant, respectively. Constrained growth of Japanese plum cv. Ozark Premier on 'Julior' has also been reported earlier by Nicotra and Moser (1999). While significantly higher plant spread (NS and EW), trunk girth, number of branches, leaf area, stomata size (length and breadth), chlorophyll content and internodal length was recorded in peach as $1.03 \mathrm{~m}, 0.97 \mathrm{~m}$, $31.69 \mathrm{~mm}, 9.18,23.30 \mathrm{~cm}^{2}, 24.91 \mu \mathrm{m} \times 16.90 \mu \mathrm{m}$, $2.41 \mathrm{mg} / \mathrm{g}$ and $1.93 \mathrm{~cm}$, respectively as compared to $0.82 \mathrm{~m}, 0.73 \mathrm{~m}, 25.88 \mathrm{~mm}, 7.95,15.04 \mathrm{~cm}^{2}, 22.87 \mu \mathrm{m}$, $16.03 \mu \mathrm{m}, 2.31 \mathrm{mg} / \mathrm{g}$ and $1.88 \mathrm{~cm}$, respectively recorded in plum. Leaf bud burst time was same in peaches and plums ( $2^{\text {nd }}$ week March) while time of leaf fall was early ( $2^{\text {nd }}$ week November) in peaches by one week as compared to plums ( $3^{\text {rd }}$ week November). From the perusal of the above findings, it seems that the differential growth of plum and peach scion cultivars on Julior is more due to genetic constitution of scion cultivars rather than that of rootstock itself. This is more reflected in plum cultivars than in peaches, where Frontier recorded almost half of the growth than that in Red Beaut. Vigorous growth of peach cv. Redhaven grafted on Julior observed in present study is in line with the findings of Perry et al. (2000) who also observed vigorous growth of Redhaven on GF677. Out of four rootstocks tested for peach cultivars, Julior imparted good vigour in an earlier study conducted by Edin et al. (1989).

While investigating performance of peach and nectarine cultivars on Prunus rootstocks, Stadler and Lotze (1991) found GF677 and Pollizo showing better growth efficiency in scion cultivars than on seedling rootstocks. Vegetative growth of peach cv. Babygold 6 was most vigorous on GF677, Dupnishka and peach x almond hybrid rootstocks as compared to PS B2, Damas 1869 and GF 43 rootstocks (Mitov and Dyakov, 1989).

\section{Conclusion}

Overall among two clonal rootstocks viz., Myrocal and Julior higher values for growth and foliage characters in scion cultivars was recorded on Myrocal followed by Julior. These observations suggest vigorous nature of Myrocal and semi-vigorous nature of Julior. To increase the production and to overcome the compatible problems both the clonal rootstocks can be utilized for propagation with Prunus cultivars studied.

\section{REFERENCES}

Ahmad, I., Cheng, Z., Liu, T., Nan, W.C., Ejaz, M., Khan, M.A. and Wasila, H. (2012). Effect of different time of budding on the bud take success of peach on peach rootstock. Advances in Environmental Biology 6(5): 1848-1852.

Bassi, G. (2003). Apricot rootstocks for cultivar S. Castrese. Informatore Agrario 59(35): 47-50. 
Beakbane, A. and Majumdar, P.K. (1975). A relationship between stomatal density and growth potential in apple. Jr. Horti. Sci. 50: 285-289.

Boyhan, G.E, Norton, J.D, Pitts, J.A. and Himelrich, D.G. (1998). Growth, yield, survival and nutrient concentrations of plums on various rootstocks. Fruit Var. Jr. 52 (2): 71-79.

Edin, M., Garcin, A. and Grasselly, C. (1989). Peaches, the performance in the orchard on four new rootstocks. Infos-Paris 54: 33-39.

Gainza, F., Opazo, I., Guajardo, V., Meza, P., Ortiz, M., Pinochet, J. and Munoz, C. (2015). Rootstock breeding in Prunus species: Ongoing efforts and new challenges. Chilean Jr. Agri. Res. 75 (Suppl. 1): 6-17

Giorgio, V. and Gallotta, A. (2000). Performance of three apricot cultivars on five rootstocks. Informatore Agrario 56: 61-63.

Gomez, K.A. and Gomez, A.A. (1984). Statistical Procedures for Agricultural Research. John Wiley and Sons, New York, 680p.

Halfacre, R.G., Baraden, J.A. and Rollens, H.A. Jr. (1968), Effect of Alar on morphology, chlorophyll content and net $\mathrm{CO}_{2}$ assimilation rate of young apple trees. Procee. Amer. Soc. Horti. Sci. 93: 40-52.

Hartmann, W. (1987). Ishtara, an interesting rootstock for plums and prunes. Obstbau 12(7): 304-305.

Hiscox, J.D. and Israeeistam, G.F. (1979). A method for extraction of chlorophyll from leaf tissue without maceration. Canadian Jr. Botany 57: 1332-1334

Hrotko, K, Magyar L, Simon G and Klenyon T. (1998). Effect of rootstocks on growth of plum cultivars in a young orchard. Acta Horti. 478: 95-98.

Makariev, Z., Milanov, B. and Poichev, K. (1986). Photosynthetic potential productivity of Golden Delicious apple trees grown under various cultural systems. Rasteniev'dni Nauki 23(3): 71-76.

Miller, E.C. (1977). Stomatal distribution as an index for predicting vigour of plum rootstocks. Indian $\mathrm{Jr}$. Horti. 34(2): 117-119.

Mitov, P. and Dyakov, D.S. (1989). The effect of different seedling and clonal rootstocks on growth and reproductive development of peach cv. Babygold 6. Rasteniev'dni Nauki 26(7): 65-69.

Nicotra, A. and Moser, L. (1999). Plum rootstocks. Informatore Agrario Supplemento 55(6): 46-50.

Nisar, N., Muhammad, J., Sher-Muhammad, Noor, R. and
Abdur, R. (2002). Performance of different stone fruits (peach, plum, apricot and almond) budded on peach rootstock under the agroclimatic conditions of Peshawar. Sarhad Jr. Agri. 18(4): 379-381.

Perry, R., Reighard, G., Ferree, D., Barden, J., Beckman, T., Brown, G. and Cummins, J. (2000). Performance of the 1984 NC-140 cooperative peach rootstock planting. Jr. Amer. Pomo. Soc. 54(1): 6-10.

Radice, S., Dessy, S., Andorno, A. and Ontivero, M. (2004). A preliminary study on the vegetative behaviour of the 'Forastero' peach cultivar grafted on different rootstocks. Acta Horti. 658: 213-219.

Renaud, R. and Salesses, G. (1994). Interspecific hybridization and rootstocks breeding for European Plums. Acta Horti. 359: 97-100.

Rozpara, E. and Grzyb, Z.S. (1994). Growth and cropping of twelve plum cultivars grafted to two rootstocks. Acta Horti. 359: 229-236

Salvador, F.R. de, Ondradu, G. and Scalas, B. (2002). Horticultural behaviour of different species and hybrids as rootstocks for peach. Acta Horti. 592: 317-322.

Schiaffino, M.R. and Radice, S. (2009). Rootstock effects on growth, yield, fruit quality and light interception in 'Forastero' (Prunus persica (L.) Batsch) peach. Adv. Horti. Sci. 23(3): 185-195

Sharma, R.L. and Sharma, R.P. (1986b). Nursery performance of some plum cultivars on important rootstocks. In: Advances in Research on Temperate Fruits, $\mathrm{T} \mathrm{R}$ Chadha, V P Bhutani and J L Kaul. (eds) Dr. YSP UHF, Nauni-Solan, pp. 149-153.

Simard, M.H. and Olivier, G. (1998). Julior ${ }^{\circledR}$-Ferdor and apricot cultivars. Arboriculture Fruitiere 523: 39-42.

Sitarek, M., Grzyb, Z.S., Guzowska-Spaleniak, B. and Lis, J. (2004). Performance of three rootstocks for plums in two different soils and climatic conditions. Acta Horti. 658: 273-277.

Stadler, J.D. and Lotze, G.F.A. (1991). Effect of seedling and clonal rootstocks on growth and yield of peach and nectarine cultivars. Jr. South Afri. Soc. Horti. Sci. 1(2): 51-54.

Webster, T. (2002). Dwarfing Rootstocks: Past, Present and Future. The Compact Fruit Tree 35(3): 67-72

Westwood, M.N. (1978). Temperate Zone Pomology, W H Freeman \& Co., San Francisco, California, 429p.

Zeb, A., Ishtiaq, M. and Noor, R. (2002). Bud take success and budding growth of peach cultivars on different rootstocks. Sarhad Jr. Agri. 18(2): 193-197. 